Brazilian Journal

of Chemical

Engineering

\title{
EXTRACTION OF BIOACTIVE COMPOUNDS OF LEAVES OF Duguetia furfuracea (ANNONACEAE) USING GREEN AND ORGANIC SOLVENTS
}

\author{
R. Favareto ${ }^{1 *}$, M. B. Teixeira ${ }^{1}$, F. A. L. Soares ${ }^{1}$, C. M. Belisário ${ }^{1}$, J. F. Cabral ${ }^{2}$, \\ E. A. da Silva ${ }^{3}$, T. A. Moia ${ }^{4}$ and L. Cardozo-Filho ${ }^{4,5}$ \\ ${ }^{1}$ Instituto Federal de Educação, Ciência e Tecnologia Goiano, Campus Rio Verde, Rio Verde, GO, Brasil. \\ E-mail: rogerio.favareto@ifgoiano.edu.br, ORCID: 0000-0001-5293-0451; ORCID: 0000-0002-0152-256X; \\ ORCID: 0000-0001-8693-6384 \\ ${ }^{2}$ Universidade Estadual de Maringá, Departamento de Zootecnia, Maringá, PR, Brasil. ORCID: 0000-0002-3664-4073 \\ ${ }^{3}$ Universidade Estadual do Oeste do Paraná, Centro de Engenharias e Ciências Exatas, Toledo, PR, Brasil. \\ ${ }^{4}$ Universidade Estadual de Maringá, Departamento de Agronomia, Maringá, PR, Brasil. \\ ${ }^{5}$ Centro Universitário da Fundação de Ensino Octávio Bastos, São João da Boa Vista, SP, Brasil. ORCID: 0000-0002-1764-9979
}

(Submitted: August 24, 2017 ; Revised: December 21, 2017 ; Accepted: March 13, 2018)

\begin{abstract}
Duguetia furfuracea (Annonaceae) is a shrub found in the Brazilian Cerrado that is used in popular medicine as an antirheumatic, for wound healing, treatment of kidney pain and against pediculosis. The aim of this study was to analyze the extraction of leaves of Duguetia furfuracea, using supercritical $\mathrm{CO}_{2}$, ethanol and hexane as solvents. For the supercritical extraction, an experimental planning $2^{3}$ with triplicates of the central point was used to evaluate the effects of temperature (313-333 K), pressure (15-23 MPa) and volumetric flow rate (3-6 mL min-1$)$ on the extraction yield, total phenolic content and antioxidant activity compared with extracts obtained by Soxhlet extraction. The effects of the variables on the extraction yield were positive and the pressure had greater influence. However, the highest performances, total phenolic content and antioxidant activities were obtained by the Soxhlet method. The mathematical model based on the Brunauer-EmmettTeller theory of adsorption correlated satisfactorily the experimental values of the supercritical extraction. Keywords: Duguetia furfuracea; Supercritical $\mathrm{CO}_{2}$; Phenolic compounds; Antioxidant activity.
\end{abstract}

\section{INTRODUCTION}

The Cerrado is a term commonly used to describe the group of ecosystems (savannas, forests, veredas and gallery forests) of the plateau in the center of Brazil (dos Santos et al., 2016, Cassino et al., 2015). It is the second largest Brazilian biome, occupying $23 \%$ of the national territory (Borges et al., 2015). The Cerrado is the most diverse tropical savanna in the world, totaling more than 12,600 species $(4,215$ Brazilian endemics) (Forza et al., 2012). Despite this, about half of the 2 million $\mathrm{km}^{2}$ of the Cerrado were turned into planted pastures, annual crops and other uses (Klink and Machado, 2005, Lambin et al., 2013) and then considered one of the world's biodiversity hotspots (Myers et al., 2000, Silva and Bates, 2002). Due to the high deforestation, large taxonomic diversity and its still understudied flora, it needs more research with native species on the conservation of natural resources and phytotherapics resources offered by medicinal plants (Guarin-Neto and Moraes, 2003).

Duguetia furfuracea (A. St.-Hil.) Benth and Hook. f. specie belongs to the Annonaceae family. It is a shrub found in the Cerrado and considered a weed by farmers for invading pastures (Lorenzi and Matos, 2002), popularly known as "sofre-do-rim-quem-quer," "araticum-bravo," "araticum-do-campo", "araticumdo-cerrado", "ata-brava", an d "ata de lobo" (Agra et

\footnotetext{
*Corresponding author: R. Favareto - E-mail: rogerio.favareto@ifgoiano.edu.br
} 
al., 2007, Silva et al., 2012). It is used in traditional medicine as an antirheumatic, for wound healing, treatment of kidney pain and against pediculosis (Silva et al., 2007).

The phytochemical analysis of the essential oil from leaves and branches of $D$. furfuracea revealed the presence of sesquiterpenes (Carollo and HellmanCarollo, 2005), flavonoids and several alkaloids (Carollo and Hellman-Carollo, 2006, Carollo et al., 2006). The alkaloid extracts obtained from the tree barks of the underground stems have antitumor, trypanocidal and leishmanicide activities (Silva et al., 2009). The ethanol extract shows cytoprotective activity with the bacterium $E$. coli against mercuric chloride, indicating that $D$. furfuracea is a promising source of cytoprotetors to combat heavy metals (Lima et al., 2014). Hexane and ethanol extracts of $D$. furfuracea have high larvicidal activity against larvae of Aedes aegypti (Rodrigues et al., 2006).

In this context, the aim of this study was to analyze the extraction of leaves of Duguetia furfuracea using supercritical $\mathrm{CO}_{2}$, ethanol and hexane as solvents. The effects of temperature, pressure and volumetric flow rate of $\mathrm{CO}_{2}$ were evaluated in the kinetics and the performance of supercritical extraction. The extracts were analyzed and compared to extracts obtained by Soxhlet using ethanol and hexane as solvents in terms of extraction efficiency, total phenolic content, antioxidant activity, and chemical composition.

\section{MATERIALS AND METHODS}

\section{Raw materials}

Samples of Duguetia furfuracea leaves were collected in the morning in April 2015, at the University of Rio Verde located in Rio Verde in the southwestern state of Goias, Brazil. The leaves were dried in a drying oven with forced circulation (Nova Etica 400 / 4ND) at $313 \mathrm{~K}$ for 24 hours. The samples were crushed in a knife mill (Solab SL-30) and then sieved through a set of W.S Tyler sieves (Mentor, OH, USA). For the extraction a sample with a grain size between 20 and 42 mesh was used.

\section{Extraction Methods \\ Soxhlet extractions}

The extractions with organic solvent were conducted according to the AOAC method (1990) using Soxhlet extractor with ethanol (Nuclear, minimum purity 99.8 $\%$ ) and hexane as solvents (Nuclear, minimum purity $99.6 \%$ ). About $5 \mathrm{~g}$ of the crushed leaves of Duguetia furfuracea were put in a filter paper cartridge and inserted into the extractor coupled to a flask containing $150 \mathrm{~mL}$ of solvent recycling over the sample. The sample was subjected to extraction for a period of 6 hours. The extractions were performed in triplicate and the results were expressed as the average \pm standard deviation.

\section{Supercritical fluid extraction (SFE)}

The extraction experiments with supercritical fluid were conducted in a laboratory scale unit as in earlier studies (Lemos et al., 2012, Silva et al., 2014, Santos et al., 2015). The unit consists of a reservoir of solvent $\left(\mathrm{CO}_{2}\right.$, White Martins SA, with $99.9 \%$ purity), one syringe pump (Isco model 500D), two thermostatic baths (Julabo F25-ME and Quimis Q214M2) and a stainless steel extractor $17 \mathrm{~cm}$ long with an internal diameter of $2.85 \mathrm{~cm}$. The experimental procedure consisted of introducing about $30 \mathrm{~g}$ samples of Duguetia furfuracea leaves inside the extractor, and then selecting the temperature and pressure desired for the experiment. After $30 \mathrm{~min}$, time to stabilize the system, it is necessary to adjust the flow rate through the micrometric valve at the bottom of the extractor and measure the extract weight every $10 \mathrm{~min}$ for a period of 3 hours.

\section{Experimental design}

A complete factorial planning $2^{3}$ with triplicate of the central point was used to evaluate the influence of pressure $(\mathrm{P})$, temperature $(\mathrm{T})$ and volumetric flow rate (Q) of $\mathrm{CO}_{2}$ on the extraction performance (Y). The encoded and uncoded values used are shown in Table 1.

The volumetric flow rate was determined at 278 $\mathrm{K}$ and pressure of the experiments. Under these conditions the $\mathrm{CO}_{2}$ density is approximately $1 \mathrm{~g} \mathrm{~mL}^{-1}$ resulting in mass flow rates of 3 and $6 \mathrm{~g} \mathrm{~min}^{-1}$.

The analysis of variance was performed using the Design-Expert software (Stat-Ease, Inc., Minneapolis, USA) by response surface methodology considering $95 \%$ of confidence by the F-Test. The general model used for variable performance response is the polynomial given by Eq. (1):

$$
\mathrm{Y}=\mathrm{b}_{0}+\sum_{\mathrm{i}=1}^{3} \mathrm{~b}_{\mathrm{i}} \mathrm{X}_{\mathrm{i}}+\sum_{\mathrm{i}, \mathrm{j}=1 ; \mathrm{i}<\mathrm{j}}^{3} \mathrm{~b}_{\mathrm{ij}} \mathrm{X}_{\mathrm{i}} \mathrm{X}_{\mathrm{j}}
$$

where $b_{0}$ is the constant fixing the performance at the central point of the experiment, $b_{i}$ are the regression coefficients for linear effects, $b_{i j}$ are the coefficients of the effects of interactions, $X_{i}$ and $X_{j}$ are the normalized independent variables.

Table 1. Operating conditions used in the extraction with supercritical $\mathrm{CO}_{2}$.

\begin{tabular}{cccc}
\hline Variables & $\mathbf{- 1}$ & $\mathbf{0}$ & $\mathbf{1}$ \\
\hline Pressure $(\mathrm{MPa})$ & 15 & 19 & 23 \\
Temperature $(\mathrm{K})$ & 313 & 323 & 333 \\
Flow rate $\left(\mathrm{mL} \mathrm{min}^{-1}\right)$ & 3.0 & 4.5 & 6.0 \\
\hline
\end{tabular}




\section{Total phenolic content (TPC)}

The determination of total phenolic content of Duguetia furfuracea extracts was performed by spectroscopy using the Folin-Ciocalteu method with modifications according to the methodology of Singleton and Rossi (1965). For analysis, the solutions were prepared by dissolving $0.1 \mathrm{~g}$ of extract in $10 \mathrm{~mL}$ of methanol, and then an aliquot of $0.1 \mathrm{~mL}$ of this solution collected and added to $7.4 \mathrm{~mL}$ of distilled water and 0.5 $\mathrm{mL}$ of Folin-Ciocalteu reagent. After three minutes, $2 \mathrm{~mL}$ of $15 \%$ aqueous solution of sodium carbonate was added and the solution left standing for 2 hours away from light, and then the absorbance measured at $760 \mathrm{~nm}$. The total phenolic content was determined through a calibration curve constructed with gallic acid used as standard and expressed in mg of GAE (gallic acid equivalents)/g extract.

\section{Antioxidant activity}

The determination of antioxidant activity was performed by the ABTS method (2,2-azino-bis (3-ethylbenzthiazoline-6-sulfonic acid)) with some modifications according to Re et al. (1999). The $\mathrm{ABTS}^{+}$radical is prepared from the reaction of $5 \mathrm{~mL}$ of $7 \mathrm{mM}$ ABTS aqueous solution with $88 \mu \mathrm{L}$ of 140 $\mathrm{mM}$ potassium persulphate solution. The mixture was kept in the dark for 16 hours. Then, $1 \mathrm{~mL}$ of this mixture was diluted in ethyl alcohol until the measured absorbance at $734 \mathrm{~nm}$ was $0.70( \pm 0.05)$. With three different dilutions of the extract, a $30 \mu \mathrm{L}$ aliquot of these dilutions was mixed with $3 \mathrm{~mL}$ of $\mathrm{ABTS}^{+}$and its absorbance measured 6 minutes after mixing. The total antioxidant activity was determined from a standard curve of Trolox and its value expressed in $\mu \mathrm{M}$ TEAC (Trolox equivalent antioxidant activity)/g extract.

\section{Gas chromatography}

The analysis of the chemical composition of the extracts was performed on a gas chromatograph (Agilent Technologies, Model 7890A) coupled to a mass spectrometry detector (Agilent Technologies, Model 5975 C). The capillary column used was a VF-WAXMS $30 \mathrm{~m} \times 0.25 \mathrm{~mm} \times 0.25 \mu \mathrm{m}$. The initial column temperature was $328 \mathrm{~K}$ rising $15 \mathrm{~K} / \mathrm{min}$ to $413 \mathrm{~K}$, then $10 \mathrm{~K} / \mathrm{min}$ to $453 \mathrm{~K}$, maintaining this for 2 $\mathrm{min}$, and $5 \mathrm{~K} / \mathrm{min}$ to $513 \mathrm{~K}$, keeping this temperature for 8 min. Helium was used as carrier gas with a flow rate of $1 \mathrm{~mL} / \mathrm{min}$. The temperatures were $553 \mathrm{~K}$ in the injector, and $553 \mathrm{~K}$ and $473 \mathrm{~K}$ in the ion source and interface, respectively. The component identification was performed by comparing their mass spectra with those from the National Institute of Standards and Technology and Kovat's indices (Adams, 1995).

\section{Modeling of the experimental data}

A model described by Pardo-Castaño et al. (2015) was used to correlate the experimental values of the supercritical extraction. The model is based on the absorption theory of Brunauer-Emmett-Teller and it expresses the extraction yield (Y) as a function of time (t) with three parameters; $y^{*}$, extract solubility in the SFE, $K$, the relationship between the solute adsorption equilibrium constant of the first monolayer and the subsequent layers and $x_{m}$, the ratio of the mass of solute present in the first monolayer and the initial mass of solute, that can be derived according to Eq. (2):

$\mathrm{t}=\frac{\mathrm{m}_{0}}{2 \dot{\mathrm{m}}_{\mathrm{f}} \mathrm{y}^{*}}\left\{\mathrm{x}_{0}^{\prime}-\mathrm{x}^{\prime}+(2-\mathrm{K})\left[\mathrm{Y}-\mathrm{x}_{\mathrm{m}} \ln \left(\frac{\alpha}{\beta}\right)\right]+\mathrm{Kx}_{\mathrm{m}} \ln \left[\frac{\alpha^{\prime}}{\beta^{\prime}(1-\mathrm{Y})^{2}}\right]\right\}$

where:

$\mathrm{x}_{0}^{\prime}=\sqrt{\mathrm{a}+\mathrm{b}+\mathrm{c}}$

$x^{\prime}=\sqrt{a(1-Y)^{2}+b(1-Y)+c}$

$\mathrm{a}=\mathrm{K}^{2}$

$\mathrm{b}=2(2-\mathrm{K}) \mathrm{Kx}_{\mathrm{m}}$

$\mathrm{c}=\left(\mathrm{Kx}_{\mathrm{m}}\right)^{2}$

$\alpha=x^{\prime}+(2-K)(1+Y)+K_{m}$

$\alpha^{\prime}=x^{\prime}+(2-K)(1-Y)+K x_{m}$

$\beta=x_{0}^{\prime}+K+(2-K) x_{m}$

$\beta^{\prime}=x_{0}^{\prime}+(2-K)+K x_{m}$

$\mathrm{y}^{*}=\mathrm{y}_{\mathrm{sat}}\left[1-\exp \left(-\frac{\mathrm{KL}}{\mathrm{u} \varepsilon}\right)\right]$

where $\mathrm{m}_{0}$ is the extractable initial mass of the solute in the packed bed, $\mathrm{m}_{\mathrm{f}}$ is the mass flow of $\mathrm{CO}_{2}, \mathrm{~L}$ is the extractor length, $\mathrm{u}$ is the speed of $\mathrm{CO}_{2}, \mathrm{y}_{\mathrm{sat}}$ is the solute mass fraction in a saturated SCF phase and $\varepsilon$ the porosity of the bed.

The objective function, defined as the average absolute relative deviation (AARD), is expressed by Eq. (13):

$$
\operatorname{AARD}=\frac{100}{\mathrm{n}} \sum_{\mathrm{t}=1}^{\mathrm{n}}\left(\frac{\mathrm{t}_{\mathrm{t}, \exp }-\mathrm{t}_{\mathrm{t}, \mathrm{cal}}}{\mathrm{t}_{\mathrm{t}, \exp }}\right)
$$


where $n$ is the number of experimental values, $t_{t, \exp }$ and $t_{t, c a l}$ are experimental times and calculated by the model, respectively.

\section{RESULTS AND DISCUSSION}

\section{Extraction yield}

Table 2 shows the experimental conditions for the extraction, extraction yield, the antioxidant activities and the total phenolic content of Duguetia furfuracea extracts obtained by supercritical $\mathrm{CO}_{2}$ and Soxhlet extractions with the organic solvents hexane and ethanol.

The analysis of variance was used to check the influence of the variables temperature, pressure and volume flow rate on the performance of the supercritical extraction at a level of $95 \%$ of confidence and to adjust the polynomial regression model as shown in Eq. (1). The results of the regression model in terms of encoded levels were significant for the F-Test and are given by Eq. (14):

$$
\mathrm{Y}=0.77+0.23 \mathrm{P}+0.041 \mathrm{~T}+0.066 \mathrm{Q}+0.053 \mathrm{PT}+0.035 \mathrm{TQ}
$$

The significant effects $(\mathrm{p}<0.05)$ were the pressure, temperature, and volumetric flow rate of $\mathrm{CO}_{2}$ and the interactions pressure-temperature, and temperatureflow rate. The effect of the pressure interaction with the flow was not significant ( $\mathrm{p}>0.05)$.

The adjusted regression coefficient was 98.6 $\%$ indicating, that the proposed model and the experimental values have good agreement. Fig. (1) shows the response surface of the extraction efficiency as a function of temperature and pressure with a constant volumetric flow rate of $6.0 \mathrm{~mL} \mathrm{~min}^{-1}$.

The positive pressure effect can be seen in both Fig. (1) and Table 2 for experiments 5 and 6, for which the yields were 0.60 and $0.92 \%$, respectively. This effect can be explained by an increase of $\mathrm{CO}_{2}$ density and consequently the solvating power of the solvent

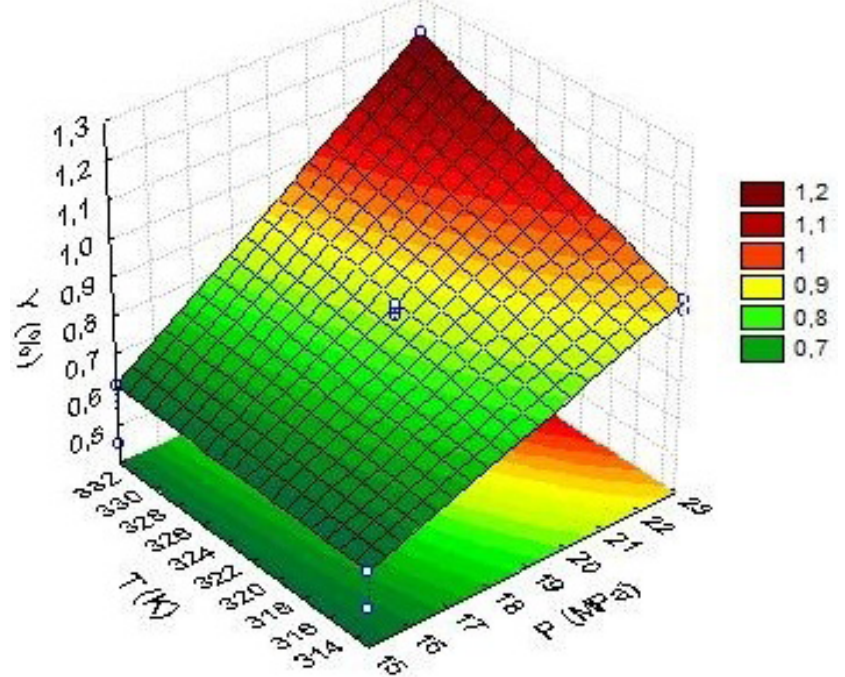

Figure 1. Influence of temperature and pressure on the $\mathrm{SFE}$ yield at constant solvent flow rate $\left(\mathrm{Q}_{\mathrm{CO} 2}=6.0 \mathrm{~mL}\right.$ $\left.\min ^{-1}\right)$.

(Paviani et al., 2012) promoted by an increase in the pressure at constant temperature. The positive effect of temperature observed in experiments 6 and 8 can be explained by the fact that, at higher temperatures, the solvent viscosity is lower and the vapor pressure of the extract greater, and consequently there is an increase in the solvent diffusivity (Goleroudbary and Ghoreishi, 2016). While the pressure and temperature affect the thermodynamic properties, such as density and solubility, and transport diffusivity, the flow rate increases the convective mass transfer coefficient and decreases the concentration of the solute in the bulk of the supercritical phase, thus obtaining a positive effect on the extraction yield (de Melo et al., 2014). The extraction by Soxhlet showed the highest results, with significant difference at the $95 \%$ confidence level. The highest yield was obtained with ethanol, which is a polar solvent. This behavior can be attributed to the higher temperature of the recirculating solvent and solute-solvent interactions (Benelli et al., 2010).

Table 2. Yields, total phenolic compounds and antioxidant activity of supercritical and Soxhlet extractions of leaves of Duguetia furfuracea.

\begin{tabular}{|c|c|c|c|c|c|c|}
\hline Exp. & $\begin{array}{c}\mathbf{P} \\
(\mathrm{MPa})\end{array}$ & $\begin{array}{c}\mathbf{T} \\
(\mathbf{K})\end{array}$ & $\begin{array}{c}Q \\
\left(\mathrm{~mL} \min ^{-1}\right)\end{array}$ & $\begin{array}{c}Y \\
(\%)\end{array}$ & $\begin{array}{c}\text { TPC } \\
\text { (mg GAE } \mathrm{g}^{-1} \text { extract) }\end{array}$ & $\begin{array}{c}\text { TEAC } \\
\left(\mu \mathrm{mol} \text { Trolox } \mathrm{g}^{-1} \mathrm{xtract}^{2}\right)\end{array}$ \\
\hline 1 & 15 & 313 & 3 & 0.51 & $53 \pm 3^{\mathrm{b}}$ & $166 \pm 2^{\mathrm{b}}$ \\
\hline 2 & 23 & 313 & 3 & 0.89 & $42 \pm 13^{\mathrm{b}}$ & $130 \pm 1^{b}$ \\
\hline 3 & 15 & 333 & 3 & 0.45 & $30 \pm 3^{b}$ & $67 \pm 0.5^{b}$ \\
\hline 4 & 23 & 333 & 3 & 0.97 & $63 \pm 120^{b}$ & $170 \pm 1^{b}$ \\
\hline 5 & 15 & 313 & 6 & 0.60 & $28 \pm 4^{\mathrm{b}}$ & $98 \pm 1^{\mathrm{b}}$ \\
\hline 6 & 23 & 313 & 6 & 0.92 & $44 \pm 1^{\mathrm{b}}$ & $102 \pm 0.3^{b}$ \\
\hline 7 & 15 & 333 & 6 & 0.61 & $32 \pm 6^{b}$ & $96 \pm 0.4^{b}$ \\
\hline 8 & 23 & 333 & 6 & 1.21 & $38 \pm 4^{\mathrm{b}}$ & $97 \pm 0.3^{b}$ \\
\hline $9 *$ & 19 & 323 & 4.5 & $1 \pm 0.01^{\mathrm{c}}$ & $31 \pm 10^{\mathrm{b}}$ & $90 \pm 18^{b}$ \\
\hline $10 *$ & Hexane & & & $2 \pm 0.2^{b}$ & $210 \pm 32^{\mathrm{a}}$ & $531 \pm 123^{\mathrm{a}}$ \\
\hline $11^{*}$ & Ethanol & & & $9 \pm 0.7^{\mathrm{a}}$ & $253 \pm 45^{\mathrm{a}}$ & $606 \pm 168^{\mathrm{a}}$ \\
\hline
\end{tabular}

Different letters indicate statistically significant difference at $5 \%$ of significance.

* Average value of three extractions; N.A: not available. 


\section{Modeling of the experimental data}

Table 3 shows the values of the parameters $\mathrm{y}^{*}, K$ and $\mathrm{x}_{\mathrm{m}}$ adjusted to the experimental values. According to Pardo-Castaño et al. (2015), a single value of $x_{m}$ encompasses all the experimental conditions studied due to its weak dependence on these conditions. This occurs because this property is dependent on the solidsolute interaction. The values of $\mathrm{y}^{*}$ are associated with solubility and can be noted that higher values, 8.04 and 5.48 for the experiments 6 and 2, respectively, are obtained for the experimental conditions of higher pressure, $23 \mathrm{MPa}$, and less temperature, $313 \mathrm{~K}$, consequently higher density of $\mathrm{CO}_{2}$.

Fig. 2 shows the correlation of experimental values and the adjusted model according to Pardo-Castaño et al. (2015).

Table 3. Adjustable parameters for the model of PardoCastaño et al. (2015).

\begin{tabular}{cccc}
\hline Exp. & $\mathbf{y}^{*} \times \mathbf{1 0}^{\mathbf{3}}$ & $\boldsymbol{K}$ & $\boldsymbol{x}_{\boldsymbol{m}}$ \\
\hline 1 & 1.60 & 66.7 & 0.591 \\
2 & 5.48 & 31.9 & 0.591 \\
3 & 1.85 & 198 & 0.591 \\
4 & 2.09 & 2.05 & 0.591 \\
5 & 1.53 & 100 & 0.591 \\
6 & 8.04 & 90.1 & 0.591 \\
7 & 1.90 & 89.6 & 0.591 \\
8 & 2.75 & 2.22 & 0.591 \\
9 & 2.97 & 21.1 & 0.591 \\
\hline
\end{tabular}

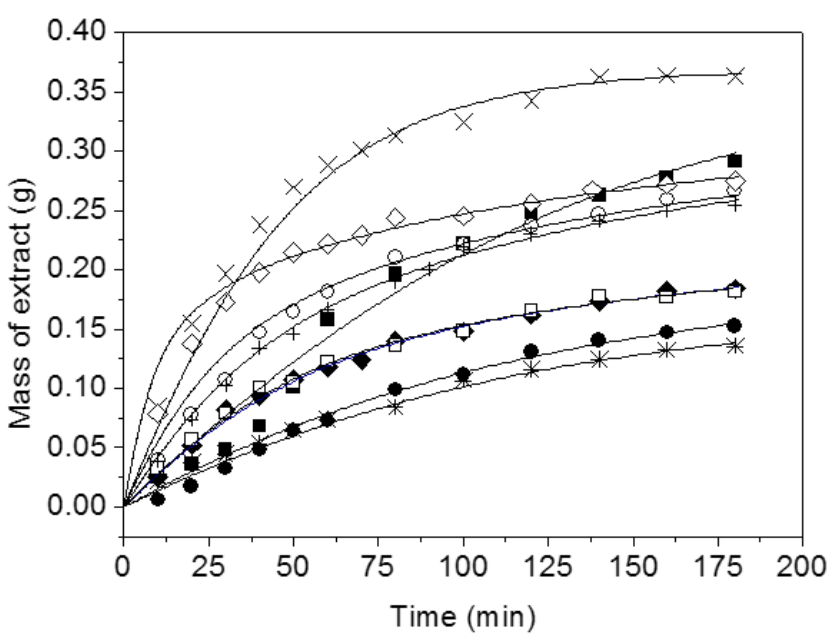

Figure 2. Calculated and experimental kinetic curves of extraction from leaves of Duguetia furfuracea: (-) model proposed by Pardo-Castaño et al. (2015); $(\bullet)$ $\operatorname{Exp} 1$; (०) $\operatorname{Exp} 2$; (*) $\operatorname{Exp} 3$; (匹) $\operatorname{Exp} 4$; (口) $\operatorname{Exp}(5)$; $(\diamond) \operatorname{Exp} 6 ;(\diamond) \operatorname{Exp} 7 ;(\times) \operatorname{Exp} 8,(+) \operatorname{Exp} 9$.

\section{Gas chromatography}

Table 4 shows the chemical composition of Duguetia furfuracea extract obtained by SFE and Soxhlet extraction with ethanol and hexane by GCMS. In the composition of the extract obtained by SFE the sesquiterpenes (+)- spathulenol and $\beta$-caryophyllene oxide prevail with 39.53 and $11.68 \%$
Table 4. Chemical composition of supercritical (SFE) and Soxhlet extracts of leaves of Duguetia furfuracea.

\begin{tabular}{lccc}
\hline \multirow{2}{*}{ Compound } & \multicolumn{3}{c}{ Relative Area \% } \\
\cline { 2 - 4 } & SFE* & Ethanol & Hexane \\
\hline Alloaromadendrene oxide-1 & 2.33 & & \\
3-Caryophyllene oxide & 11.68 & 5.18 & 4.95 \\
(+)-Spathulenol & 39.53 & 20.35 & 13.80 \\
Ethyl palmitate & & 3.61 & \\
Spathulenol & 1.64 & & \\
(-)-Caryophyllene oxide & 3.08 & & \\
Methyl elaidate & 2.19 & 10.47 & 2.63 \\
Aromadendrene oxide-2 & 3.63 & & \\
Alloaromadendrene oxide-2 & 2.34 & & \\
(-)-Spathulenol & 2.53 & & \\
Isoaromadendrene epoxide & 3.22 & & \\
2-Methylenocholestan-3-ol & 3.15 & 5.33 & \\
$\alpha-$ Tocoferol & & 2.87 & \\
Palmitic acid & 6.32 & & \\
3-Deoxyestradiol & & 28.41 & 7.12 \\
2-Methylhexadecan-1-ol & 3.55 & & \\
Not identified & 14.81 & 23.79 & 71.54 \\
\hline
\end{tabular}

* Average value of three extractions at the center point $(19 \mathrm{MPa}, 323 \mathrm{~K}$ and $\left.4.5 \mathrm{~mL} \mathrm{~min}^{-1}\right)$.

of relative area, respectively. For the ethanol extract, the main component was 3-deoxyestradiol with 28.41 $\%$ of relative area.

In the three extracts, it is important to emphasize the presence of spathulenol, a component that has been shown to have multiple biological activities, including antimicrobial, insecticidal and cytotoxic (Cantrell et al., 2005). This component also predominates in the chemical composition of the essential oil of Duguetia furfuracea leaves, according to Valter et al. (2008).

\section{Total phenolic content (TPC)}

The values of total phenolic content of SFE and Soxhlet extracts are shown in Table 2. In the supercritical extraction model, the results presented no significant difference, showing no dependence of the total phenolic content with pressure, temperature and volumetric flow. The values of TPC ranged from 28 to $62 \mathrm{mg} \mathrm{GAE} \mathrm{g}^{-1}$ of extract and showed no statistical difference at the 5\% significance level. The TPC values for ethanol and hexane extracts differed significantly at $5 \%$ from the extracts obtained by SFE, and presented values of 253 and $210 \mathrm{mg}$ GAE $\mathrm{g}^{-1}$ of extract, respectively. The TPC of the ethanol extract agrees with the results of other species of the Annonaceae family, such as the methanol extract of the twigs of the species Duguetia riparia (Cunha, 2009) and the ethanol extract of Annona cherimoya Mill. (Rabelo et al., 2014).

\section{Antioxidant activity}

Table 2 shows the values of the antioxidant activity of Duguetia furfuracea extracts performed by the ABTS method. The highest values obtained were 606 and $531 \mu \mathrm{M}$ Trolox g-1 extract for ethanol and hexane 
extracts, respectively. For the supercritical extraction the antioxidant activity values were not significantly different, showing no dependence of the antioxidant activity with pressure, temperature and volumetric flow. The ABTS values for the extracts ranged from 67 to $170 \mu \mathrm{mol}$ Trolox $\mathrm{g}^{-1}$ of extract. As expected, the extracts with higher total phenolic content showed the highest antioxidant activity. Pereira et al. (2013) also obtained higher values of ABTS for ethanolic extract of Myrtus communis L. in comparison with the supercritical extract.

\section{CONCLUSION}

The best extraction yield with supercritical $\mathrm{CO}_{2}$ of Duguetia furfuracea was $1.21 \%$, with the highest pressure $(23 \mathrm{MPa})$, highest temperature $(333 \mathrm{~K})$, and highest volume flow rate $\left(6 \mathrm{~mL} \mathrm{~min} \mathrm{~m}^{-1}\right)$. The values of yield were adjusted to a polynomial model with all the positive effects of variables, so that the pressure was the variable that had the greatest effect. The regression coefficient of $98.6 \%$ indicates that the polynomial model can be used under the evaluated conditions. The total phenolic content and antioxidant activity showed no significant difference between the experiments with SFE. However showed higher values for TPC, 253 and $210 \mathrm{mg} \mathrm{GAE} \mathrm{g}^{-1}$ of extract, and TEAC, 606 and $531 \mu \mathrm{M}$ Trolox $\mathrm{g}^{-1}$ extract, for ethanol and hexane extracts. The chemical profile of the extracts obtained showed high levels of spathulenol, especially for SFE. The simple mathematical model proposed by Pardo-Castaño et al. (2015) satisfactorily correlated the experimental data with the calculated values.

\section{ACKNOWLEDGEMENT}

The authors thank CAPES and CNPq for the financial support.

\section{REFERENCES}

A.O.A.C., Official methods of analysis, 11 ed., Association of Official Agricultural Chemists, Washington. D.C. (1990).

Adams, R. P., Identification of essential oil components by gas chromatography/quadrupole mass spectrometry, Allured Publishing, Carol Stream, IL (1995).

Agra, M. F., França, P. F., Barbosa-Filho, J. M., Synopsis of the plants known as medicinal and poisonous in Northeast of Brazil. Brazilian Journal of Pharmacognosy, 17, 114-140 (2007). https://doi. org/10.1590/S0102-695X2007000100021

Benelli, P., Riehlb, C.A. S., Smania Junior, A., Smaniac, E. F. A., Ferreira, S. R. S., Bioactive extracts of orange (Citrus sinensis L. Osbeck) pomace obtained by SFE and low pressure techniques: Mathematical modeling and extract composition. The Journal of Supercritical Fluids, 55, 132-141 (2010). https:// doi.org/10.1016/j.supflu.2010.08.015

Borges, P. P., de Andrade Oliveira, K. A. F., Machado, K. B., Vaz, U. L., da Cunha, H. F., Nabout, J. C., Trends and gaps of the scientific literature on the Cerrado biome: a scientometric analysis. Neotropical Biology and Conservation, 10, 2-8 (2015). https://doi.org/10.4013/nbc.2015.101.01

Cantrell, C. L., Klun, J. A., Bryson, C. T., Kobaisy, M., Duke, S. O., Isolation and identification of mosquito bite deterrent terpenoids from leaves of American (Callicarpa americana) and Japanese (Callicarpa japonica) beautyberry. Journal of Agricultural and Food Chemistry, 53, 5948-5953 (2005). https://doi. org/10.1021/jf0509308

Carollo, C. A., Hellman-Carollo, A. R., Siqueira, J. M., Albuquerque, S., Alkaloids and a flavonoid from aerial parts (leaves and twigs) of Duguetia furfuracea - Annonaceae. Journal of the Chilean Chemical Society, 51, 837-841 (2006). https://doi. org/10.4067/S0717-97072006000200001

Carollo, C. A., Hellmann, A. R., Siqueira, J. M., Sesquiterpenoids from the essential oil from leaves of Duguetia furfuraea (Annonaceae). Biochemical Systematics and Ecology, 33, 647-649 (2005). https://doi.org/10.1016/j.bse.2004.09.004

Carollo, C. A., Siqueira, J. M., Garcez, W. S., Diniz, R., Fernandes, N. G., N-Nitrosoanonaine and N-Nitrosoxylopine, Aporphine Alkaloids from Duguetia furfurace.. Journal of Natural Products, 69, 1222-1224 (2006). https://doi.org/10.1021/np0600191

Cassino, R. F., Martinho, C. T., Caminha, S. A. F. S., Modern pollen spectra of the Cerrado vegetation in two national parks of Central Brazil, and implications for interpreting fossil pollen records. Review of Palaeobotany and Palynology, 223, 71-86 (2015). https://doi.org/10.1016/j. revpalbo.2015.09.002

Cunha, L. M. A., Estudo Fitoquímico e Biológico de Duguetia riparia (Annonaceae), in Universidade Federal Do Amazonas, Manaus (2009).

da Silva, D. B., Tulli, E. C. O., Militão, G. C. G., Costa-Lotufo, L. V., Pessoa, C., de Moraes, M. O., Albuquerque, S., de Siqueira, J. M., The antitumoral, trypanocidal and antileishmanial activities of extract and alkaloids isolated from Duguetia furfuracea. Phytomedicine, 16, 1059-1063 (2009). https://doi.org/10.1016/j.phymed.2009.03.019

de Melo, M. M. R., Solvestre, A. J. D., Silva, C. M., Supercritical fluid extraction of vegetable matrices: Applications, trends and future perspectives of a convincing green technology. The Journal of Supercritical Fluids, 92, 115-176 (2014). https:// doi.org/10.1016/j.supflu.2014.04.007 
dos Santos, A. J., Vieira, T. B., Faria, K. C., Effects of vegetation structure on the diversity of bats in remnants of Brazilian Cerrado savanna. Basic and Applied Ecology, 17, 720-730 (2016). https://doi. org/10.1016/j.baae.2016.09.004

Forzza, R. C., Baumgratz, J. F. A., Bicudo, C. E. M., Canhos, D. A. L., Carvalho Jr., A. A., Coelho, M. A. N., Costa, A. F., Costa, D. P., Hopkins, M. G., Leitman, P. M., Lohmann, L. G., Lughadha, E. N., Maia, L. C., Martinelli, G., Menezes, M., Morim, M. P., Peixoto, A. L., Pirani, J. R., Prado, J., Queiroz, L. P., Souza, S., Souza, V. C., Stehmann, J. R., Sylvestre, L. S., Walter, B. M. T., Zappi, D. C., New Brazilian floristic list highlights conservation challenges. BioScience, 62, 39-45 (2012). https:// doi.org/10.1525/bio.2012.62.1.8

Goleroudbary, M. G. and Ghoreishi, S. M., Response surface optimization of Safranal and Crocin extraction from Crocus sativus L. via supercritical fluid technology. The Journal of Supercritical Fluids, 108, 136-144 (2016). https://doi.org/10.1016/j. supflu.2015.10.024

Guarim-Neto, G.and Morais, R. G., Medicinal plants resources in the Cerrado of Mato Grosso State, Brazil: a review. Acta Botanica Brasilica, 17, 561-584 (2003). https://doi.org/10.1590/S010233062003000400009

Klink, C. A. and Machado, R. B., Conservation of the Brazilian Cerrado. Conservation Biology, 3, 707-713 (2005). https://doi.org/10.1111/j.15231739.2005.00702.x

Lambin, E. F., Gibbs, H. K., Ferreira, L., Grau, R., Mayaux, P., Meyfroidt, P., Morton, D. C., Rudel, T. K., Gasparri, I., Munger, J., Estimating the world's potentially available cropland using a bottomup approach. Global Environmental Change, 23, 892-901 (2013). https://doi.org/10.1016/j. gloenvcha.2013.05.005

Lemos, C. O. T., Garcia, V. A. S., Gonçalves, R. M., Leal, I. C. R., Siqueira, V. L. D., Cardozo-Filho, L., Cabral, V. F., Supercritical extraction of neolignans from Piper regnelli var. pallescens. The Journal of Supercritical Fluids, 71, 64-70, (2012). https://doi. org/10.1016/j.supflu.2012.07.003

Lima, C. N. F., Valero, T. F., Leite, N. F., Alencar, L. B. B., Matias, E. F. F., Kerntopf, M. R., Coutinho, H. D. M., Protective action of Duguetia furfuracea (A. St.-Hil.) Saff. against toxicity due to mercury chloride in Escherichia coli. Revista Cubana de Plantas Medicinales, 19, 179-188 (2014).

Lorenzi, H.and F. J. A.Matos, Medicinal Plants in Brazil: Native and Exotic, Plantarum Institute, Sao Paulo, Brazil, 2002.

Myers, N., Mittermeier, R. A., Mittermeier, C. G., da Fonseca, G. A. B., Kent, J., Biodiversity hotspots for conservation priorities. Nature, 403, 853-858 (2000). https://doi.org/10.1038/35002501
Pardo-Castaño, C., Velásquez, M., Bolaños, G., Simple models for supercritical extraction of natural matter. The Journal of Supercritical Fluids, 97, 165-173 (2015). https://doi.org/10.1016/j. supflu.2014.09.044

Paviani, L. C., Saito, E., Dariva, C., Marcucci, M. C., Sánchez-Camargo, A. P., Cabral, F. A., Supercritical $\mathrm{CO}_{2}$ extraction of raw propolis and its dry ethanolic extract. Brazilian Journal of Chemical Engineering, 29, 243-251 (2012). https://doi.org/10.1590/S010466322012000200005

Pereira, P., Bernardo-Gil, M. G., Cebola, M. J., Mauricio, E., Romano, A., Supercritical fluid extracts with antioxidant and antimicrobial activities from myrtle (Myrtus communis L.) leaves. Response surface optimization. The Journal of Supercritical Fluids, 83, 57-64 (2013). https:// doi.org/10.1016/j.supflu.2013.08.010

Rabêlo, S. V., da Costa, M. M., Libório, R. C., da Silva Almeida, J. R. G., Antioxidant and antimicrobial activity of extracts from atemoia (Annona cherimola Mill. x A. squamosa L.). Revista Brasileira de Fruticultura, 36, 265-271 (2014). https://doi. org/10.1590/S0100-29452014000500031

Re, R., Pellegrini, N., Protegente, A., Pannala, A., Yang, M., Rice Evans, C., Antioxidant activity applying in improved ABTS radical cátion decolorization assay. Free Radical Biology and Medicine, 26, 1231-1237 (1999). https://doi.org/10.1016/S08915849(98)00315-3

Rodrigues, A. M. S., de Paula, J. E., Degallier, N., Molez, J. F., Espíndola, L. S., Larvicidal activity of some Cerrado plant extracts against Aedes aegypti. Journal of the American Mosquito Control Association, 22, 314-317 (2006). https://doi. org/10.2987/8756-971X(2006)22[314:LAOSCP]2 .0.CO;2

Santos, K. A., Bariccatti, R. A., Cardozo-Filho, L., Schneider, R., Palú, F., Silva, C., Silva, E. A. Extraction of crambe seed oil using subcritical propane: Kinetics, characterization and modeling. The Journal of Supercritical Fluids, 104, 54-61 (2015). https://doi.org/10.1016/j. supflu.2015.05.026

Silva, D. B., Tulli, E. C. O., Garcez, W. S., Nascimento, E. A., Siqueira, J. M., Chemical constituents of the under-ground stem bark of Duguetia furfuracea (Annonaceae). Journal of the Brazilian Chemical Society, 18, 1560-1565 (2007). https://doi. org/10.1590/S0103-50532007000800017

Silva, I. C. M., Santos, W. L., Leal, I. C. R., Zoghbi, M. G. B., Feirhmann, A. C., Cabral, V. F., Macedo, E. N., Cardozo-Filho, L., Extraction of essential oil from Cyperus articulatus L. var. articulatus (priprioca) with pressurized $\mathrm{CO}_{2}$. The Journal of Supercritical Fluids, 88, 134-141 (2014). https:// doi.org/10.1016/j.supflu.2014.02.001 
Silva, J. M. C. and Bates, J. M., Biogeographic patterns and conservation in the South American Cerrado: a tropical savanna hotspot. BioScience, 52, 225-233 (2002). https://doi.org/10.1641/00063568(2002)052[0225:BPACIT]2.0.CO;2

Silva, M. A. B., Melo, L. V. L, Ribeiro, R. V., Ethnobotanical survey of plants used as antihyperlipidemic and the anorectic population of New Xanthine-MT, Brazil. Brazilian Journal of Pharmacognosy, 20, 540-562 (2010).

Singleton, V. L. and Rossi, J. A., Colorimetry of Total Phenolics with Phosphomolybdic-Phosphotungstic
Acid Reagents. American Journal Enology and Viticulture, 16, 144-158 (1965).

Valter, J. L., Alencar, K. M. C., Sartori, A. L. B., Nascimento, E. A., Chang, R., de Morais, S. A. L., Laura, V. A., Yoshida, N. C., Carollo, C. A., da Silva, D. B., Grassi, R. F., Fabri, J. R., de Siqueira, J. M., Chemical variability of the essential oil of the leaves from six individuals of Duguetia furfuracea (Annonaceae). Brazilian Journal of Pharmacognosy, 18(3), 373-378 (2008). https://doi. org/10.1590/S0102-695X2008000300011 